\title{
PRIEKŠSTATI PAR NĀCIJAS TAPŠANU: PRIMORDIĀLISMA TRIUMFS PĀR MODERNIZĀCIJU?
}

\section{Gints Apals}

Dr. hist., neatkarīgs pētnieks

Zinātniskās intereses: ideju vēsture, ǵeopolitika, starptautiskās attiecības.

Sabiedrībā valdošos priekšstatus par nācijas un valsts veidošanos Latvijas teritorijā pamatvilcienos nosaka ilgstoši kultivēts vēstures mìts, kas nepārtraukti tiek atražots ne vien izglītības sistēmā un kultūras procesos, bet arī plašsaziņas līdzeklı izplatītajā politiskajā retorikā. Vēstures zinātne, kas ir finansiāli atkarīga no valsts varas labvēlības, neizbēgami pakḷaujas politiskajiem imperatīviem un tiecas atražot konkrētajā laika posmā definētos postulātus. Līdz ar to arī jautājums par nācijas veidošanos Latvijas teritorijā nereti tiek atvasināts no valsts interesēm, pārnesot iespējami tālā pagātnē 20. gadsimta gaitā nostiprinātos priekšstatus par vēlamo sabiedrības modeli.

Valdošā vēstures paradigma no jauna formulēta 2014. gadā pieņemtajā Satversmes preambulā - "Latvijas valsts ir izveidota, apvienojot latviešu vēsturiskās zemes un balstoties uz latviešu nācijas negrozāmo valstsgribu [..] Latvijas identitāti Eiropas kultūrtelpā kopš senlaikiem veido latviešu un lībiešu tradīcijas, latviskā dzīvesziņa, latviešu valoda, vispārcilvēciskās un kristīgās vērtības".

Šajā formulā iebūvēta doma, ka duālas izcelsmes (latviešu un lībiešu!) un valodas kopības definētā nācija ir Latvijas valsts un Latvijas tautas pamats. Tās veidošanās saistīta ar nekonkrētiem senseniem laikiem un aptuvenu priekšstatu par latviešu vēsturiskajām zemēm, kas pašsaprotami ietver arī lỉbiešu teritoriju. Šāda konstrukcija grūti saprotama bez zināšanām par Andreja Pumpura daiḷradi, ${ }^{1}$

1 Eposa "Lāčplēsis" 2. dziedājumā A. Pumpurs postulēja, ka "Sensenos laikos Baltijas zemē [..] Dzīvoja laimīga latviešu tauta”. 
vēsturniekiem tā atstāj vienīgi iespēju diskutēt par senseno laiku hronologiskajām robežām.

Tomēr 21. gadsimta apstākḷlos nacionālais vēstures mīts nevar būt pietiekams ideologiisks pamats pilsoniskas un iekḷaujošas sabiedrības veidošanai, kā arī Latvijas mijiedarbībai ar ārpasauli. Starp politiski definētajiem priekšstatiem par valsts genēzi un mūsdienu izaicinājumiem pastāv plaisa, kuras aizpildīšanai nepietiek ar Satversmes preambulas deklaratīvajiem postulātiem. ${ }^{2}$

Šīs plaisas aizpildī̌̌ana prasa ne tikai vēsturnieku, bet arī citu sabiedrisko zinātṇu disciplīnu pārstāvju iesaisti. Tādā virzienā sperti daži soḷi. Piemēram, Latvijas Zinātṇu akadēmijas Humanitāro un sociālo zinātṇu nodaḷas rīkotā diskusija "Latvieši - politiskā vai kultūras nācija?” 2021. gada 7. maijā un Turaidas muzejrezervāta organizētā diskusija "Latviešu nācija. No tautas uz nāciju" 2021. gada 4. septembrī. ${ }^{3}$

Abu pasākumu kopsaucējs ir centieni konstruēt pēctecīgu saikni starp cilvēku kopības formām visā laika posmā no 12. līdz 20. gadsimtam, bet centrālais jautājums - latviešu tautas pārtapšana par nāciju, kā arī kultūras nācijas un politiskās nācijas jēdzienu attiecināšana uz šo procesu. Lai gan domu apmaiņas gaitā netiek apšaubìta cēloṇsakarība starp nācijas un modernas valsts veidošanos, tajā prevalē doma, ka latviešu tauta kā etniska kopība ir nācijas vienīgais dabiskais pamats un 19.-20. gadsimta ciña par varu Latvijas teritorijā bija tikai agrāko gadsimtu etnisko pretrunu turpinājums. Alternatīvas sabiedrības organizācijas formas šādā diskursā neiekḷaujas, līdz ar to ārpus diskusijas ietvariem paliek nācijas genēzes konceptuālā problēma primordiālisma un modernizācijas pieeju konflikts Latvijas vēsturē.

\section{PRIMORDIĀLISMS UN MODERNIZĀCIJA}

Latvijas vēsturnieku skatījums uz nācijas veidošanās jautājumu tradicionāli iekḷaujas primordiālisma paradigmā. Tas balstās uzskatā, ka etniska kopība ir dabiska un teju vai mūžìga, bet pasaules politiskā

2 "Latvija kā demokrātiska, tiesiska, sociāli atbildīga un nacionāla valsts balstās uz cilvēka cieṇu un brīvību, atzīst un aizsargā cilvēka pamattiesības un ciena mazākumtautības. [..] Latvija, apzinoties savu līdzvērtību starptautiskajā kopienā, aizstāv valsts intereses un veicina vienotas Eiropas un pasaules ilgtspèjīgu un demokrātisku attīstību."

3 Informācija par abām diskusijām un to ieraksti atrodami LZA HSZN mājaslapā https://www.lza.lv/nodalas/humanitaro-un-socialo-zinatnu-nodala. 
organizācija nacionālās (faktiski - etniski homogēnās) valstīs ir gan vēstures procesa mērḳis, gan taisnīgas sabiedrības priekšnoteikums. Latvijas sociologe Inese Šūpule raksta: "Primordiālisti etniskumu raksturo kā pārlaicīgu, cilvēku kopienām piemìtošu fenomenu [..] etniskums tiek aplūkots kā cilvēku kopumu raksturojošs aspekts neatkarīgi no vēsturiskajiem, sociālajiem vai politiskajiem faktoriem. Etniskās grupas, nācijas tiek aplūkotas kā dabīgi jeb biologiski noteikti fenomeni, tās tiek uzskatītas par radinieku klanu paplašinājumu."

Vairums Latvijas vēsturnieku absolutizē primordiālos pieņēmumus un attiecina tos uz laiku pirms nāciju veidošanās, kas pasaules vēsturē saistāms ar 19. gadsimtu. Tikai pēc Franču revolūcijas un britu Amerikas koloniju neatkarības sasniegšanas suverenitāte pamazām sāka pāriet no valdnieka personas uz tautu. Veidojās nācijas kā tiesībās un pienākumos vienlīdzīgu pilsoṇu kopums (pretstatā kārtu sabiedrībai), notika zemāko sabiedrības slāṇu emancipācija, kas skāra arī latviešu zemniekus Krievijas impērijas Baltijas provincēs un Vitebskas guberṇā.

Tomēr etniski viendabīgas nācijas veidošanās ne tuvu nav vienīgais iespējamais šì procesa rezultāts. Modernas nacionālas valstis ne vienmēr ir etniski homogēnas, to tapšana 19.-20. gadsimtā nereti saistīta ar dažādu etnokulturālo grupu mijdarbību, saplūstot vienā politiskā nācijā uz vēsturiska valstiskuma precedenta pamata. Raksturīgi piemēri Eiropā būtu Somija un Beḷgija.

Sociologijas klasiķis Makss Vēbers postulējis, ka etnisko grupu saliedēšanās pamatā ir subjektīva pārliecība par kopīgu izcelšanos, nevis reāla kopīga izcelšanās un asinsradniecība. Turklāt ticība kopējai izcelsmei var tikt radìta un uzturēta tikai kopīgā sociālā un politiskā darbībā, identificēšanās ar noteiktu etnisko grupu veidojas politiskās mobilizācijas rezultātā. ${ }^{5}$ Šādas atziṇas neizbēgami ved pie alternatīvas Latvijas vēstures interpretācijas. Tā var tikt balstìta sociālā konstrukcionisma priekšstatos par to, ka kolektīvā identitāte vienmēr ir vēsturiski, sociāli un politiski noteikta, turklāt tā mainās līdzi laikam.

4 Šūpule, Inese (2012). Etniskās un nacionālās identitātes sociālā konstruēšana mijiedarbībā: Latvijas gadījuma izpēte. Promocijas darbs. Rīga: Latvijas Universitāte, 53. lpp. Pieejams: https://www.szf.lu.lv/fileadmin/user_upload/szf_faili/Petnieciba/ promocijas_darbi/Inese_Supule_Promocijas\%20darbs_aizsargats.pdf.

5 Turpat, 54. lpp. 
No šāda viedokḷa nācijas veidošanās ir saistīta vienīgi ar kvalitatīvi jaunas sabiedrības tapšanu 19. gadsimta modernizācijas gaitā, šis process neizbēgami neizriet no iepriekšējo gadsimtu sociālās realitātes. Iespējams argumentēt, ka dzimtbūšanas atcelšana, privātīpašuma tiesību nostiprināšanās (ieskaitot zemnieku zemes īpašuma veidošanos), urbanizācija un migrācija, izglītības process un masu komunikācija Baltijas provincēs un Vitebskas guberñā radīja priekšnoteikumus jaunas sabiedrības tapšanai. Tikai daži Latvijas vēsturnieki skata nācijas veidošanos šādā aspektā - piemēram, Vita Zelče ${ }^{6}$ un šì raksta autors. ${ }^{7}$

Valdošais viedoklis Latvijas vēstures zinātnē joprojām saistīts ar primordiālismā sakṇotu vēlēšanos likt vienādības zīmi starp etniskas kopienas (latviešu tautas) un nācijas jēdzieniem, tādējādi latviešu elitei piešķirot ekskluzīvas tiesības uz politisko un ekonomisko varu. Tiesa, kā raksta mūsdienu Igaunijas autors Martins Ehala, ${ }^{8}$ etniskums un nācija zināmā mērā ir vienas lielas dihotomijas varianti. Abi divi tiecas definēt sabiedrības pamatgrupu, kam ideālā gadījumā ir kopēja valoda, teritorija, vēsture, religijija un kolektīvā identitāte. Šādā izpratnē nācija tiešām ir tikai viens no etniskuma attīstības posmiem, kā to neatlaidīgi atkārto latviešu nacionālā vēstures mīta adepti.

No otras puses, mūsdienu sabiedriskās zinātnes uzsver nācijas jēdziena saikni ar sociālo konstrukcionismu. Proti, nācijas tiek apzināti veidotas, lai kalpotu instrumentālām vajadzībām - pārveidotu sabiedrību. No šāda viedokḷa nācija ir nesena un vēsturiski nosacìta parādība cilvēces vēsturē - iedomāta kopiena, nevis reāla grupa, kuras locekḷus vieno personiska saikne. Tai nav tieša sakara ar etniskumu, līdz ar to nacionālā identitāte kḷūst brīvi konstruējams un mainīgs lielums. Taču primordiālisms un etnolingvistisko kopienu arguments daudzos gadījumos pamato prasības, lai sabiedrība tiktu pārveidota atbilstoši etniskās nācijas koncepcijai. ${ }^{9}$ Šeit izpaužas arī viens no Latvijas vēstures paradoksiem - tieši 19. gadsimta modernizācija nostiprināja primordiālus mītus, ar kuriem joprojām tiek saistīta nācijas un valsts tapšana.

6 Zelče, Vita (2018). Jaunlatvieši. No: Latvija un latvieši: Akadēmiskie raksti. 2. sēj. Rīga: Latvijas Zinātņu akadēmija, 309.-335. lpp.

7 Apals, Gints (2011). Pēterburgas Avīzes. Latviešu pirmā saskare ar Eiropas politiskajām idejām. Rīga: Zvaigzne ABC.

8 Ehala, Martins (2014). Etniskās un nacionālās identitātes Baltijas valstīs. No: Juris Rozenvalds, Aija Zobena (zin. red.). Daudzveidīgās un mainīgās Latvijas identitātes. Rīga: LU Akadēmiskais apgāds, 33.-34. lpp.

9 Turpat. 


\section{NACIONĀLĀ IDENTITĀTE KĀ JAUNRADES PROCESS}

Vēsturnieki un sociologi ir izmantojuši šìs atzinas, lai radìtu teorētiskus model̦us, kas skaidro nāciju tapšanu 19. gadsimtā un meklē kopsakarības vismaz reǵiona mērogā. Latvijas gadijumā ievērību pelna divi no tiem. Amerikāņu sociologa Hansa Kona darbos liberālais nacionālisms tiek šķirts no etniskā nacionālisma. Rietumeiropā nācijas veidošanās balstījās jau pastāvošajās pilsoniskajās institūcijās un vēsturiskos valstiskuma precedentos. Centrālajā un Austrumeiropā nācijas jēdziens tika traktēts organiskās un kolektīviskās kategorijās. Nācijas veidotāji tur bija intelektuāḷi, kas ienesa apritē modernas idejas, manipulējot ar dažādām atmiṇām, simboliem, mītiem un identitātēm. Savu roku šāda nacionālisma tapšanā pielika romantisma kustība ar tās akcentiem uz mistisko tautas dvēseli, mītisko, heroisko senatni un iracionālismu. ${ }^{10}$

Līdzīgu modeli piedāvāja Čehoslovākijas marksistiskais vēsturnieks Miroslavs Hrohs, kurš Centrālās un Austrumeiropas nāciju génēzē saskata trīs periodus: A - zinātniskās intereses periods, B - patriotiskās agitācijas periods un $\mathrm{C}$ - masu nacionālās kustības rašanās periods. Latviešu nacionālās kustības attīstībā tomēr nav iespējams novilkt tik striktas līnijas, jo tajā visu triju fāžu darbības norisinājās nevis secīgi, bet gan paralēli un mijiedarbīgi. ${ }^{11}$

Abu model̦u kopīgais elements ir tas, ka nacionālās identitātes elementi tiek brīvi konstruēti, balstoties uz subjektīviem pieņēmumiem par tālu pagātni un kultūras arhetipiem, taču sociālo procesu pēctecība ar nesenām norisēm tiek noliegta. Latviešu nacionālās kustības gadījumā par identitātes konstruēšanas pamatu kḷuva Garlība Merķeḷa publicistika, sevišķi viṇa darbs "Vidzemes senatne”, kas jau 1799. gadā izvirzīja priekšstatus par "zelta laikmeta" (un arī latviešu tautas) pastāvēšanu 12. gadsimtā, seno cilvēku izcilajām ètiskajām ipašīibām un pat viṇu fizisko tipu.

Šajos priekšstatos iebūvēta absolūta negācija pret jebko, kas noticis starplaikā līdz 18. gadsimta beigām. Vienlaikus tie atbalso vācu nacionālistu (Johana Gotfrīda Herdera, Johana Gotlība Fihtes, Ernsta Morica Arnta, Vilhema Humbolta u. c.) idejas par to, ka

10 Ijjabs, Ivars (2014). Starp etnisko un pilsonisko: daži apsvērumi par nacionālās identitātes problēmu. No: Juris Rozenvalds, Aija Zobena (zin. red.). Daudzveidīgās un main̄īgās Latvijas identitātes. Rīga: LU Akadēmiskais apgāds, 28. lpp.

11 Zelče. Jaunlatvieši, 312. lpp. 
valodas kopībai jāveido politiskās kopības pamats, jebkuras tautas individualitāte izpaužas tās valodā, paradumos un kopīgajā pieredzē (t. i., vēsturiskajā atmiṇā). ${ }^{12}$

Aktīva latviešu nacionālās identitātes konstruēšana sākās līdz ar jaunlatviešu kustības veidošanos. Šis process par vairākām desmitgadēm apsteidza objektīvas informācijas uzkrāšanu par vēsturi, valodniecību vai etnogrāfiju. Būtībā tas bija kultūras jaunrades process ar politisku nolūku. Jau 19. gadsimta 50. gadu beigās Juris Alunāns publicēja kategoriskus apgalvojumus par latviešu tautas pagātni un tās īpašỉbām. Jaunlatviešu privātajā sarakstē 19. gadsimta 60. gadu sākumā izpaudās ambīcijas fundamentāli pārveidot Baltijas provinču iekārtu, apvienojot Kurzemi un Vidzemes latviešu daļu vienā administratīvā vienībā, piešķirot latviešu valodai oficiālu statusu, dodot zemniekiem zemes īpašuma tiesības un plašu pārstāvību provinces līmeṇa pārvaldes struktūrās. ${ }^{13}$

Lai gan šo ideju pārtapšana konkrētos reformu plānos prasīja divas desmitgades, nacionālās identitātes attīstība kultūras jaunrades procesā notika daudz straujāk. Nacionālais romantisms producēja neskaitāmus simbolus, kas nostiprināja priekšstatus par etniskajā kopībā un valodā balstītu identitāti, sekmējot latviešu norobežošanos no citiem Baltijas provinču sabiedrības segmentiem un dodot pamatu jaunās elites cerībām uz varas pārdali savā labā.

Nacionālās kustības priekšgalā nostājās Rīgas Latviešu biedrības aprindas, kas lìdz pat 19. gadsimta 90. gadiem sekmīgi izmantoja nacionālo romantismu savas atbalsta bāzes paplašināšanai ārpus ekonomiski motivēto personu (lauku saimnieku slāṇa un pilsētu vidusšķiras) loka, tādējādi to instrumentalizējot. Vienlaikus kultūras jaunrades process formulēja latviešu nacionālo vēstures mītu, summējot galvenos priekšstatus par pagātni un nākotni Andreja Pumpura 1888. gadā publicētajā eposā "Lāčplēsis".

\section{VĒSTURNIEKU LOMA}

Latvijas pagātnes pētniecība vienmēr palikusi nacionālā vēstures mīta ēnā, šì situācija nav principiāli mainījusies līdz pat šim brīdim vēsturniekiem ir tikai sekundāra loma nacionālās identitātes veido-

12 Connelly, John (2020). From Peoples into Nations: a History of Eastern Europe. Princeton: Princeton University Press, pp. 84-85.

13 Sk.: Apals. Pēterburgas Avīzes. Latviešu pirmā saskare ar Eiropas politiskajām idejām, 115., 155. lpp. 
šanā. Viṇu darba uzdevumi un sabiedriskā nozīmība ir tieši atkarīga no politiskās un ekonomiskās elites vai valsts varas, kas izvirzījusi mērķi radīt jaunu Latvijas vēsturi, izslēdzot vai minimizējot laika posmus, kur latvieši vai to iedomātie senči nav bijuši noteicošais faktors vēstures notikumos. Būtībā jau kopš t. s. pirmās atmodas laika vēsturniekiem tika dots uzdevums ilustrēt nacionālo mītu, paplašinot vai padzilịnot atsevišķus aspektus, taču neapšaubot galvenos postulātus.

Ja sākotnēji jaunlatviešu politisko mērḳu pamatošanai pietika ar kultūras jaunradi un Merḳeḷa domugraudiem, tad samērā izglītotas un organizētas nacionālās elites nostiprināšanās 19. gadsimta 80. gados radīja nepieciešamību pēc izvērstāka pagātnes traktējuma. Frīdrihs Veinbergs publicēja brošūru "Iz latviešu-leišu vēstures", kas deva skaidru ievirzi: "Tā sauktā Baltijas vēsture pa lielākai daḷai tik ir Baltijas vāciešu vēsture [..] ir cita vēsture, kas latviešiem stāv daudz tuvāk [..] tā ir leišu vēsture [..] latviešu-leišu tautas liktenis jau kopš veciem laikiem vēsturiski saistīts ar krievu tautas likteni [..] lielākā uzplaukšana panākta sabiedrībā ar krievu tautu." ${ }^{4}$

Jauno skatījumu uz pagātni Veinbergs viennozīmīgi saistīja ar krievu nacionālistu (slavofilu) un panslāvistu priekšstatiem par vēsturi kā mūžìgu cinnu starp slāviem un germāṇiem, ${ }^{15}$ tādējādi atspogulojot nacionālās kustības cerības panākt varas pārdali Baltijā ar Krievijas valdības palīdzību: "Šai kultūras cīnā pret vācietības izplatīšanos uz austrumu tagad nu latviešiem piekrīt izpildīt svarīgāko lomu [...] uzturēt un attīstìt savu tautību, lai nenotiktu latviešu vai vismaz lielas latviešu dal̦as pārvācošana [..] vienīgi caur to var aprobežot vācietības tālāku izplatǐšanos." 16

Lai gan informācija par Latvijas vēstures avotiem latviešu valodā tika publicēta jau kopš 19. gadsimta 60. gadiem (piemēram, ziṇas par Indriķa hroniku), plašākas avotu publikācijas sekoja tikai 19. gadsimta 80. gados. Pirmais akadēmiski izglītotais latviešu vēsturnieks Jānis Krodznieks (Krīgers) profesionālo kvalifikāciju ieguva 1878. gadā, taču turpmāk aprobežojās ar atsevišķiem rakstiem par vēstures tematiku latviešu presē. Pirmais apkopojošais darbs par Latvijas vēsturi latviešu valodā bija marksista Kārḷa Landera grāmata, ko izdeva Maskavā 1908.-1909. gadā.

14 Veinbergs, Frīdrihs (1885). Iz latviešu-leišu vēstures. Rīga, 5.-6. lpp.

15 Sk.: Connelly. From Peoples into Nations: a History of Eastern Europe, p. 94.

16 Veinbergs. Iz latviešu-leišu vēstures, 96.-98. lpp. 
Starpkaru periodā Latvijā vēstures pētniecība progresēja ne sevišḳi strauji. Atmetot agrāko orientāciju uz krievu kultūru vai marksismu, vēsturnieki saglabāja fundamentālu Baltijas vēstures noliegumu. Šì posma rezultātus vēlāk raksturoja Edgars Andersons: "Latvijas universitātes vēstures nodaḷā toreiz vēl dominēja baltvācu vēsturnieki [..] visus notikumus Latvijā vērtēdami no vācu kolonizatoru viedokḷa un latviešus neuzskatīdami pat par tautu, bet zemāku šķiru. Radās "nacionālo kaujinieku” grupa, kas [..] sāka vēsturi pētīt un rakstīt no latviešu tautas viedokḷa, brǐžiem gan pazaudējot sakaru ar apkārtējo pasauli. Viṇi Latvijas vēsturi iztīrīja no kolonizatoru sārņiem, bet daži brīžiem aizgāja pretējos ekstrēmos. Latvijas vēsture kḷuva izolēta, patstāvīga vienība."17

Politiskie mērķi, kas pamatoja vēstures pētniecības virzienu, tika skaidri definēti tikai Kārḷa Ulmaņa prezidēšanas laikā. 1936. gadā izglītības ministrs Augusts Tentelis deklarēja: "Mūsu mērḳis ir nacionāla vēsture, mūsu tautas un mūsu Latvijas vēsture [..] karstas mīlestības pilna, pilna cēla lepnuma un varonības apziṇas." ${ }^{18}$ Tajā pašà gadā dibinātajam Latvijas Vēstures institūtam ar likumu tika dots uzdevums strādāt nacionālisma un patiesības garā, pētot latviešu senvēsturi, latviešu vecāko vēsturi, latviešu jaunāko vēsturi un (visbeidzot) arī vispārīgo vēsturi. Bet ne Livonijas, ne Baltijas vēsturi.

Līdz ar to Latvijas pagātne pilnīgi oficiāli tika pielīdzināta latviešu tautas vēsturei. Šajā tradīcijā darbu turpināja arī trimdas vēsturnieki, radot pirmo apkopojošo pētījumu sēriju par Latvijas vēsturi apgāda "Daugava” izdevumā. Padomju okupācijas periodā vēsturnieki Latvijā radīja lielu skaitu pētījumu, kas padziḷināja izpratni par sociālajiem un ekonomiskajiem procesiem, taču kopumā pagātni traktēja no šḳiru cīņas viedokḷa.

Neviena no šìm skolām nevar dot adekvātu pamatu nācijas genēzes procesa izpratnei. Latvijas vēsture kā disciplīna arī šobrīd ir šauri fokusēta uz lokālu mērogu un tiecas ignorēt plašāku kontekstu, atsakoties salīdzināt vietējās norises ar procesiem Baltijas jūras reǵiona, Eiropas vai pasaules mērogā. L,oti iespējams, ka iepriekš citētās Edgara Andersona atziņas par Latvijas vēstures izpētes stāvokli ir spēkā arī 21. gadsimtā.

17 Andersons, Edgars (1973). Dr. Arnolds Spekke. Jaunā Gaita, 92, 56. lpp.

18 Tentelis, Augusts (1937). Patiesība un nacionālisms vēstures zinātnē un mācīšanā. No: Francis Balodis (red.). Vēstures atziņas un tēlojumi. Rīga: Izglīīibas ministrija, 7.-18. lpp. 
Varētu domāt, ka izeja no Latvijas vēstures apburtā loka ir sadarbība ar citu sabiedrisko zinātṇu pārstāvjiem vietējā vai starptautiskā mērogā ar nolūku veikt starpdisciplinārus pètījumus, kas iziet ārpus primordiālisma paradigmas. Taču tādu pētījumu mērogs prasa atbilstošu finansējumu, kura iegūšana valsts pētījumu programmu ietvaros ir problemātiska. Politiski noteiktie pētījumu virzieni sabiedriskajās zinātnēs paši par sevi atražo primordiālos priekšstatus par Latvijas vēsturi, skatot latviešu un mazākumtautību identitāti Latvijas vēsturē kā šķirtus pētījuma objektus, ko labākajā gadījumā iespējams harmonizēt, aktualizējot "konceptuālo ietvaru". ${ }^{19}$ Nācijas veidošanās un nacionālā identitāte kā tāda pagaidām nepieder pie vēlamajiem pètījumu virzieniem.

Primordiālie priekšstati tiek nepārtraukti atražoti un nostiprināti politiskā līmenī. Pat 2021. gadā pieṇemtais un izsludinātais "Latviešu vēsturisko zemju likums" nācijas tapšanu atvasina no 12 . gadsimta realitātes, nosakot, ka "latviešu vēsturiskajās zemēs uz kuršu, latgalıu, sēḷu un zemgal̦u sentautu, kā arī seno pirmiedzīvotāju - lībiešu kultūras un valodas bāzes veidojusies latviešu nācija".

Šāda redakcija pilnībā ignorē Latvijas vēsturisko dalıu (kas Satversmes 3. pantā definētas kā Vidzeme, Latgale, Kurzeme un Zemgale) robežas, radot jaunu veidojumu - Sēliju. Lìdz ar to Livonijas, Baltijas provinču un Inflantijas vēstures noliegums tiek pacelts vēl augstākā pakāpē nekā iepriekš. Izceḷot jēdzienu "latviešu nācija", lietojot grūti definējamo terminu "latvietỉba" un izvairoties no vārdkopas "Latvijas tauta”, šis likums noliedz vācbaltiešu, krievu, poḷu, ebreju un citu vietējo etnokulturālo kopienu pilntiesīgu iekḷaušanos Latvijas politiskajā nācijā, reducējot minēto grupu vēsturisko lomu uz mazākumtautības statusu. Šādos apstākḷos tālākas zinātniskas diskusijas par nācijas tapšanu Latvijas teritorijā šḳiet liekas.

19 2021. gada 7. jūlija Ministru kabineta rīkojums Nr. 475 Par valsts pētījumu programmu "Letonika latviskas un eiropeiskas sabiedrības attīstībai". https://likumi.lv/ ta/id/324651-par-valsts-petijumu-programmu-letonika-latviskas-un-eiropeiskassabiedribas-attistibai. 


\section{THE BIRTH OF A NATION: THE TRIUMPH OF PRIMORDIALISM OVER MODERNISATION?}

\section{Gints Apals}

Dr. hist., independent scholar.

Research interests: the history of ideas, geopolitics, international relations.

The paper discusses two competing conceptual approaches to the issue of nation-building. The predominant school of thought draws its inspiration from the primordial myth developed in the course of the $19^{\text {th }}$ century. It argues that the Latvian nation should be defined in terms of ethnic origins: only the presumed descendants of the local tribes populating the territory of Latvia in the $12^{\text {th }}$ century could be considered as full members of the nation, and other ethnic groups should be seen as national minorities posessing separate identities. Representatives of this school tend to focus on the transition of the ethnic Latvian people into a full-fledged nation, making an effort to distinguish two separate stages of the nation-building - the cultural phase and the political one.

Only a few historians (but many more sociologists) interpret the nation-building in terms of modernisation that fundamentally changed the society. These scholars follow the social constructionist approach and do not regard the national identity as an inherited quality. From such a perspective the idea of an ethnically homogeneous nation stems from political ambitions of the new Latvian-speaking elites who successfully built their support base using primordial assumptions and much more real economic contradictions between Latvian-speaking peasantry and German-speaking upper class.

The construction of an exclusive Latvian identity is a part of transformative cultural process. Over a few decades in the second half of the $19^{\text {th }}$ century, activists created a powerful set of mobilising symbols that imposed a new identity on Latvian-speaking population and helped develop a sense of common cause. In this respect historians played a secondary role. The nationalist ideology has always been based on the rejection of the history of Livonia and the Baltic provinces. To this day, historians are expected to substantiate the claim that the whole history of Latvia is a perpetual struggle for freedom from foreign oppression and the modern Latvian state embodies the final triumph over alien forces. 